I на завершення звернемося до Вім Вендерса, німецького кінорежисера, голови Європейської кіноакадемії: «Діти сьогодні все бачать ... I я би хотів, щоб ми могли розповісти їм трохи, як читати між зображеннями - подібно до того, як ми дізнавалися 3 книг, як читати між рядками».

\title{
Література:
}

1. Баликін І.Г., Волошенюк О.В, Чорний О.В, Федченко О.С. Абетка візуальної грамотності. Київ : Центр Вільної Преси, 2019. 123 с.

\section{DOI https://doi.org/10.30525/978-9934-26-042-1-15}

\section{DYPLOMACJA CYFROWA JAKO NARZĘDZIE POLITYKI ZAGRANICZNEJ PAŃSTWA}

\author{
Kotsiuba V. V. \\ Doktorantka Wydziatu Stosunków Międzynarodowych \\ Wolyńskiego Uniwersytet Narodowy im. Lesi Ukrainki \\ Łuck, Ukraina
}

Pojęcie dyplomacji niesie w sobie wiele znaczeń. W perspektywie makro termin „dyplomacja» można traktować jako proces prowadzenia stosunków międzynarodowych poprzez nagocjacje lub inne środki o charakterze pokojowym. Natomiast w perspektywie mikro dyplomację możemy określić jako narzędzie polityki zagranicznej państwa za pomocą którego podmioty stosunków międzynarodowych prowadzą własne interesy. Własnie ten drugi aspekt jest nam nięzbędny dla zrozumienia niniejszej pracy [1, s. 20-21].

Od dawna pojęcie dyplomacji było utożsamiane tylko i wyłącznie $\mathrm{z}$ nawiązywaniem lub utrzymywaniem stosunków między państwami. Natomiast obecnie tradycyjne kontakty dyplomatyczne zaczynają tracić swoją pierwotną funkcję oraz ustępują miejsce nowym narzędziom. $\mathrm{Z}$ rozwojem stosunków międzynarodowych zaczęły pojawiać się nowe drogi komunikacji oraz nowe podmioty stosunków dyplomatycznych. Informacje zdobywane przez ambasadorów nie są już na tyle ważne w nawiązywaniu kontaktów między państwami, jak to było wcześniej. Dynamiczny rozwój stosunków międzynarodowych wymaga coraz większej efektywności oraz 
nowych narzędzi polityki zagranicznej państw. Jednym z takich narzędzi jest dyplomacja cyfrowa.

Komunikowanie się za pomocą Internetu prowadzi do rozwoju nowych zjawisk oraz przenoszenia niektórych obszarów życia do sieci. Rzeczy wcześniej niemożliwe dla dyplomatów, stały się rzeczywistością, jak np. prowadzenia skutecznej dyplomacji za pomocą mediów społecznościowych czy innych kanałów internetowych. Ciągły rozwój mediów społecznościowych na nieowyobrażalną dotąd skalę spowodował potrzebę angażowania się w tych obszarach ekonomistów, polityków, dyplomatów. W taki sposób powstała właśnie dyplomacja cyfrowa lub e-dyplomacja, cyberdyplomacja, dyplomacja medialna (pojęcia te stosują się wymiennie) [2, s. 2-4].

Rewolucja teleinformacyjna, polegająca na przekazie internetowym oraz wykorzystaniu nowych mediów, umożliwiła rozwijanie form realizacji interesów państwa w płaszczyźnie międzynarodowej. Dyplomacja cyfrowa okazała się $\mathrm{w}$ danej sytuacji jedną $\mathrm{z}$ najlepiej skutecznych metod oraz praktyk dyplomatycznych. Wykorzystywanie Internetu oraz mediów społecznościowych $\mathrm{w}$ dyplomacji $\mathrm{z}$ każdym rokiem przybiera coraz większego znaczenia. Coraz większa liczba podmiotów działających na międzynarodowej scenie politycznej oraz wzrastająca liczba kanałów komunikacji między nimi wymaga redefinicji form, metod oraz narzędzi prowadzenia dyplomacji we współczesnym świecie[3, s.1-4]. Przeniesienie działań dyplomatycznych do trybu online oraz wykorzystanie nowych osiągnięc technologicznych $\mathrm{w}$ codziennej pracy polityków, niewątpliwie wyodrębniło nowy rodzaj dyplomacji - dyplomację cyfrową.

Internet otworzył nową przestrzeń dla dyplomacji, pozwalającą udostępnianie oraz upowszechnianie treści dostępnych wszystkim zainteresowanym osobom. To $\mathrm{z}$ kolei umożliwiło znacznie szybsze wpływanie na światową opinię publiczną. Wcześniej tradycyjny sposób rozpowszechniania informacji przez dyplomatów zasadniczo opierał się na przekazie za pomocą przemówień oraz komunikatów przekazywanych $\mathrm{W}$ dalszej kolejności do radia lub telewizji. Natomiast obecnie aktywność ta $\mathrm{W}$ coraz większym stopniu przenosi się do Internetu. Dyplomaci pomimo oficjalnych platform udostępnianych prez rządowe agendy, wykorzystują social media. Swoją aktywność lokują oni w odpowiednich wirtualnych przestrzeniach, gdzie dostosowują swój przekaz do potrzeb oraz zaineresowań odbiorców.

Zaletą stosowania takich cyberdyplomatycznych technik jest szybkość oraz łatwość docierania do publiczności. Mimo tego, równy dostęp do narzędzi z zakresu dyplomacji cyfrowej umożliwia publikowanie treści przez wszystkich dyplomatów bez wzgłędu na ich rangę lub doświaczenie. 
Niektóre państwa, tak jak na przykład Wielka Brytania, już od dawna opracowują strategie szkolenia pracowników agend dyplomatycznych $\mathrm{w}$ obszarach nowych technologii. W ostatnich latach to właśnie media społecznościowe stały się ważnym ogniwem prowadzenia dyplomacji. Rekrutowanie oraz szkolenie „e-dyplomatów» jest skierowane na aktywne podejmowanie działań w sferze mediów społecznościowych, takich jak np. Facebook, Twitter czy YouTube.

Pomiędzy social media a dyplomacją cyfrową szczególna rola przypisuje się Twitterowi. Inaczej mówiąc, możemy określić go mianem dyplomatycznego „barometru», czyli narzędziem służączym do analizy oraz prognozowania stosunków międzynarodowych. Czasem nawet możemy usłyszeć pojęcie Twiplomacji. Jeżeli chodzi o kwestie rozwijania sieci dyplomatycznych i cyfrowych, to Ministerstwa Spraw Zagranicznych obserwują siebie nawzajem oraz tworzą koalicje w określonych tematach (jednym ztakich przykładów jest walką z ISIS w 2016 roku). To własnie media społecznościowe są często używanym narzędziem w strategiach dyplomatycznych państw [3, s. 6-9].

Przykładem praktycznego zastosowania dyplomacji cyfrowej jako instrumentu polityki zagranicznej jest Federalna Republika Niemiec. To właśnie dla władz niemieckich proces cyfrazcji był oraz jest ,siła napędową oraz katalizatorem» społecznego i gospodarczego rozwoju świata. Według rządu władz niemieckich jak działania, tak i myślenia międzynarodowe z ubuegiem czasu będą $\mathrm{w}$ coraz większym stopniu określane przez cyfryzacje oraz rozwój Internetu. Więcej tego, to systemy komputerowe są „układem nerwowym społeczeństw», wpływającym na funkcjonowanie państwa. Dlatego ochrona oraz rozwój sieci i jej infrastruktury jest kluczowym zadaniem dla Niemiec.

Rząd niemicki uważa, że siły transformujące Internet mają ogromny wpływ na kwestię praw człowieka, a konkretnie chodzi tutaj o wolność słowa. To właśnie Internet jest motorem bogactwa społeczeństw oraz ma istotny wpływ na naszą wolność. $Z$ kolei nieograniczony dostęp do informacji jest nieodłącznym prawem człowieka oraz sprzyja jego osobistemu rozwoju. Przykładem tu mogą posłużyć rewolucje w Afryce Północnej jeszcze w roku 2011. Byłyby one niemożliwe bez cyfrowych narzędzi komunikacyjnych, które dodały obywalelom tych państw „skrzydeł do walki». Jeszcze w roku 2012, za kadencji Guido Westerwelle ówczesnego Ministra spraw zagranicznych, rząd niemicki wygłosił wolność w Internecie jako ważny cel polityki zagranicznej RFN.

Niemieckie Ministerstwo Spraw Zagranicznych ma stronę intrnetową, która jest tłumaczona na siedem języków obcych oraz kanał na YouTube. Na tym kanałe urzędnicy zamieszczają filmy zawierające informacje np. o 68 
funkcjonowaniu niemieckiej służby zagranicznej, najważniejszych wydarzeniach na świecie czy stanowisku władz niemieckich wobec tych tematów. Często to też mogą być filmy o konferencjach prasowych kanclerz federalnej lub ministra spraw zagranicznych Niemiec; o działaniach dotyczących praw człowieka, wołności słowa i prasy, walki z ubóstwem czy ochroną środowiska; czy też o kulturzę i biężących wydarzeneniach w kraju. Każdy, chcący wybrać się do Niemiec, może zapoznać się z praktycznymi informacjami o Niemczech w ojczystym jemu języku. Możliwość dostępu do informacji poprzez platformę cyfrową sprzyja budowaniu przyjaznego wizerunku państwa dla turystów oraz zachęca do odwiedzania [1, s. 159-164].

A więc, rozwój cyberprzestrzeni dał światu nowy instrument w postaci dyplomacji cyfrowej. Jest ona nowym narzędiem do realizacji polityki zagranicznej państw. Rozwój dyplomacji medialnej niesie za sobą nowe zmiany oraz nową jakość we współczesnych stosunkach międzynarodowych [2, s. 12-13]. Wykorzystanie nowych technologii w działalności dyplomatycznej skutkuje pojawieniem się nowych sposobów osiągania celów polityki zagranicznej państw w cyfrowym systemie międzynarodowym. Czynniki takie jak szybkość przekazu, bezpośredniość, powszechność oraz łatwość dostępu do informacji sprzyjają rozwojowi efektywnej dyplomacji medialnej. Wykorzystanie danego narzędzia polityki zagranicznej wymaga, oczywiszcie, jeszcze dużej pracy oraz zrozumienia dynamiki cyfrowych mediów. Osoby mające do czynienia z polityką zagraniczną muszą zrozumieć dynamikę zjawisk zachodzących w danym obszarze oraz nauczyć się posługiwać się narzędziami jakie udostępnia im Internet. Współcześne środowisko międzynarodowe wymaga szybkiego adptowania się do zmian, gdzie Internet oraz dyplomacja medialna zajmują kluczowe miejsce [3, s. 13].

\section{Bibliografia:}

1. Dyplomacja cyfrowa jako instrument polityki zagranicznej XXI, red. Kosienkowski M., Piskorska B., Lublin, Wydawnictwo KUL, 2014, file:///C:/Users/Windows\%208.1/Desktop/\%D1\%86\%D0\%B8\%D1\%84\%D $1 \% 80 \% \mathrm{D} 0 \% \mathrm{BE} \% \mathrm{D} 0 \% \mathrm{~B} 2 \% \mathrm{D} 0 \% \mathrm{~B} 0 \% 20 \% \mathrm{D} 0 \% \mathrm{~B} 4 \% \mathrm{D} 0 \% \mathrm{~B} 8 \% \mathrm{D} 0 \% \mathrm{BF} \% \mathrm{D} 0$ $\%$ BB $\%$ D0\%BE\%D0\%BC\%D0\%B0\%D1\%82\%D1\%96\%D1\%8F.pdf

2. Kusztykiewicz A., Dyplomacja cyfrowa - nowa forma polityki zagranicznej Unii Europejskiej, 2017, file:///C:/Users/Windows\%208.1/ Downloads/1030-897.pdf

3. Broś N., Znaczenie nowych technologii dla współczesnej dyplomacji, Uniwersytet Wrocławski, 2017， file:///C:/Users/Windows\%208.1/ Downloads/16647-39967-1-PB.pdf 